\title{
Autolytic Enzymes as a Source of Error in the Preparation and Study of Gram-negative Cell Walls
}

\author{
BY W. WEIDEL, H. FRANK AND W. LEUTGEB \\ Max-Planck-Institut für Biologie, Abt. Weidel, Tübingen, Germany
}

(Received 22 May 1962)

\begin{abstract}
SUMMARY
The cell wall of Salmonella gallinarum, like that of other Gram-negative organisms, was found to contain a separate continuous rigid mucopolymer layer. This structure was rapidly broken down by the cell's own enzymes during wall preparation when suitable precaution against this action was not taken. Possible errors in the interpretation of cell-wall structure, deriving from this and other causes, are discussed.
\end{abstract}

\section{INTRODUCTION}

Recent work on Gram-negative cell-wall structure has led several authors, working independently, to differing views about the mucopolymer component of the wall (cf. Shafa \& Salton, 1960; Work, 1961; Weidel, Frank \& Martin, 1960). The opposing views are that the wall contains no continuous separate mucopolymer layer or that it does contain such a layer ( $R$-layer). Its absence was concluded from two sets of observations. Shafa \& Salton (1960) found complete disaggregation by anionic detergents of walls prepared according to their methods. Work (1961), on the other hand, found a complex spectrum of peptides to be released from walls of Escherichia coli by enzymes of lysozyme-like character, and interpreted these peptides as containing typical mucopolymer components linked to sets of amino acids derived from protein. Her conclusion was that "each of the so-called "layers" contained mucopeptide components'.

Since our own results seemed to demonstrate clearly the existence of a separate mucopolymer layer in the walls of Escherichia coli (Weidel et al. 1960) and other Gram-negative micro-organisms (Martin \& Frank, 1962a; Schocher, Bayley \& Watson, 1962), the simplest interpretation of the findings of Shafa \& Salton (1960) is that their wall preparations no longer contained an intact mucopolymer layer. As found recently in this laboratory, the empty Gram-negative cell wall does not necessarily disintegrate spontaneously even upon thorough destruction of its $R$-layer with lysozyme (Martin \& Frank, 1962b). Hydrogen or other non-covalent bonding between components of the outer wall layers is sufficiently strong to keep them together, thereby preserving the shape of the cell wall fairly well; but by interfering with these weak bonds, mechanically or by anionic detergents, such a precarious structure disintegrates completely. It is easy to see how damage can be done inadvertently to the $\boldsymbol{R}$-layer during wall preparation. For theoretical reasons, the cell must contain enzymes for the specific purpose of systematically hydrolysing certain covalent bonds which hold the $\boldsymbol{R}$-layer together, otherwise the wall could not grow (Weidel et al. 1960). If not inactivated during wall preparation, these enzymes 
can be expected to digest the $R$-layer, with the result that such cell walls can indeed be disintegrated by detergent alone. With Gram-negative organisms especially, the damaging effect of the enzymes is likely to be rapid and efficient, since the $R$-layer is extremely thin and closest to the cytoplasm, which is difficult to remove completely from the walls.

Two early observations were taken by us as directly indicating the presence and activity of such enzymes within Escherichia coli. First, most of the cell walls of E. coli in preparations made by our old method which involves a prolonged period of 'autolysis' under toluene (Weidel, 1951) are obtained as rounded-off rather than oblong forms. Secondly, cell walls prepared in this way yielded, on incubation of their phenol-insoluble fraction with lysozyme, proportions of the two main mucopolymer split products $\mathrm{C}_{5}$ and $\mathrm{C}_{6}$ (Primosigh, Pelzer, Maass \& Weidel, 1961) which varied from preparation to preparation. In the hope of suppressing both effects, the procedure for wall preparation was changed so as to use the enzyme-inhibiting powers of sodium dodecylsulphate (SDS) at the earliest possible stage. When this was done, only oblong cell walls were obtained, in which the presence of a separate $\boldsymbol{R}$-layer was now easily demonstratable.

Thus one is confronted with the apparent paradox that the very agent which in the hands of Shafa \& Salton led to complete disintegration of their cell-wall preparations, served to preserve our walls in good shape. We thought it advisable therefore to investigate this paradoxical phenomenon further with one of Dr Salton's own cultures, and he kindly sent us his strain of Salmonella gallinarum for the purpose.

\section{The R-layer of Salmonella gallinarum}

The organisms were grown at $37^{\circ}$ on a shaker for $9 \mathrm{hr}$. in nutrient broth (500 ml.), spun down and carefully resuspended in $200 \mathrm{ml}$. distilled water. To this suspension, $200 \mathrm{ml}$. of a $4 \%(\mathrm{w} / \mathrm{v})$ SDS solution in water were added. The suspension became very viscous, and was allowed to stand overnight at about $20^{\circ}$, after which it was diluted to $1600 \mathrm{ml}$. with water and centrifuged at $66,000 \mathrm{~g}$. The sediment was taken up in $200 \mathrm{ml}$. water, the suspension treated briefly with DNAase and RNAase ( $\mathrm{Mg}^{++}$added) and centrifuged at $66,000 \mathrm{~g}$. The sediment was then resuspended in $4 \%(w / v)$ SDS solution, shaken for $1 \mathrm{hr}$. with glass beads in a Mickle disintegrator, washed three times with water on the centrifuge at $23,500 \mathrm{~g}$ and then shaken for $1 \mathrm{hr}$. in $4 \%(\mathrm{w} / \mathrm{v})$ SDS solution. This was followed by six more washings on the centrifuge. Electron microscopic control showed the sediment now to consist of cell walls unchanged in shape, more than two-thirds of them completely empty (Pl. 1, fig. 1). Since we had the impression that most of the wall lipopolysaccharide had already been removed (contrary to the behaviour of Escherichia coli strain B lipopolysaccharide), phenol dissociation was omitted and the final proteolytic digestion effected immediately with either trypsin or pepsin. Either enzyme released material which still covered the mucopolymer layer of these walls without being arranged in a pattern of tightly packed spheres, as with $\boldsymbol{E}$. coli. What was not solubilized of this material remained deposited on or beside the empty mucopolymer bags (Pl. 1, fig. 2), but could be removed now by washing the sedimented mixture three times at $23,500 \mathrm{~g}$, then shaking the deposit in $4 \%(\mathrm{w} / \mathrm{v})$ SDS solution for $15 \mathrm{~min}$. and washing again ten times at $66,000 \mathrm{~g}$. The final sediment consisted of pure mucopolymer layers of Salmonella gallinarum cell walls (P1. 1, fig. 3). 
As expected, this material dissolved completely in a buffered solution of lysozyme. The chromatographic pattern of ninhydrin-positive split products yielded by the lysozyme treatment had a marked qualitative and quantitative resemblance to that obtained with a lysozyme digest of the Escherichia coli mucopolymer layer (Primosigh et al. 1961; Pl. 2, fig. 4). There was only one major spot (X) between $\mathrm{C}_{3}$ and $\mathrm{C}_{4}$ which was either absent from or much weaker on the $E$. coli chromatogram. The similarity of the two patterns was confirmed by the determination of the molar ratios of muramic acid, glutamic acid, diaminopimelic acid and alanine in a hydrolysate of pure Salmonella mucopolymer (methods described by Primosigh et al. 1961). In this sequence, they were found to be $1.02: 1 \cdot 01: 0 \cdot 99: 1 \cdot 00: 1 \cdot 84$ (mean of four determinations). Comparable protein-free mucopolymer bags from $E$. coli $\mathbf{B}$ gave ratios of $1: 1: 1: 1: 1 \cdot 8$ (Martin \& Frank, 1962b). Other amino acids were not detectable on the chromatograms run for quantitative analysis.

\section{Disappearance of the $\mathrm{R}$-layer from unstabilized cell walls}

After establishing the presence in the Salmonella gallinarum cell wall of a continuous separate mucopolymer layer, walls of this organism were prepared according to Shafa \& Salton (1960), i.e. Mickle disintegrator treatment of organisms suspended in distilled water, thorough washing of the cell-wall fraction and treatment with trypsin. Plate 2, fig. 5, shows an electronmicrograph of this cell-wall preparation, which was not further washed in order not to lose anything. The walls are definitely deformed, as compared to walls shown in Pl. 1, fig. 1. The turbid suspension of these cell walls when mixed with one-tenth of its volume of $4 \%(w / v)$ SDS solution cleared almost immediately, and electron microscopy of the mixture then revealed no structures resembling cell walls or mucopolymer bags among the debris (Pl. 2, fig. 6), thus confirming the findings of Shafa \& Salton (1960) and, at the same time, our interpretation of this result.

\section{DISCUSSION}

The lesson to be learnt from the foregoing is that 'a cell wall is not a cell wall is not a cell wall', i.e. is not nearly as static an object as might be thought. Just because in the complete Gram-negative cell wall (as opposed to the wall of Gram-positive organisms) the mucopolymer layer is only a minor (yet functionally highly important) component, it is an especially sensitive indicator of shifts in the interplay of the enzymes building and rebuilding it. This is illustrated by the fact that we found the structure of the Escherichia coli mucopolymer to change even during the short time it takes to spin down the organisms from the liquid culture, resuspend them and treat them with SDS or heat for stabilization. Lysozyme digests of mucopolymer from such organisms contain the components $\mathrm{C}_{5}$ and $\mathrm{C}_{6}$ (fig. 4; see also Primosigh et al. 1961) in a molar ratio of about $1: 2$. Shortening the time between harvesting the organisms and blocking the degradative enzymes noticeably decreases the ratio. But in order really to 'freeze' the mucopolymer structure in the form in which it exists in the fully active cells, one has to squirt the culture into boiling water immediately after stopping aeration. Then the mucopolymer yields almost no $\mathrm{C}_{5}$, but correspondingly more $C_{6}$ instead. This is explained by the finding of one of our colleagues that $E$. coli cells contain an enzyme capable or removing C-terminal D-alanine from the peptide chain of the $\mathrm{C}_{6}$ subunit of the mucopolymer, thereby 
changing it into a $\mathrm{C}_{5}$ subunit (Pelzer, 1962). For structural analysis of the Gramnegative cell wall it is essential to keep in mind, in addition to the necessity of working with stabilized wall material, that the whole structure is established through the intricate co-operation of covalent and non-covalent bonds. This means that upon destruction of the supporting mucopolymer layer, e.g. with lysozyme, a host of wall components will be freed, most of which are anything but lysozyme split products. These non-mucopolymer components may have contributed to the multitude of peptides encountered by Work (1961) in her lysozyme digests of $E$. coli cell walls. Judging from the chemical nature of split products obtained, it seems possible that her cell-wall preparations contained a variety of active hydrolytic enzymes, including proteolytic ones. We feel that it is unsafe to draw conclusions about cell wall structure unless the various wall layers are separated as far as possible, before analysing their components (Weidel \& Primosigh, 1957; Martin \& Frank, 1962b).

\section{REFERENCES}

Martin, H. H. \& Frank, H. (1962a). Die Mucopeptid-Grundstruktur in der Zellwand Gram-negativer Bakterien. Zbl. Bakt. (1. Abt. Orig.), 184, 306.

Martin, H. H. \& Frank, H. (1962b). Quantitative Bausteinanalyse der Stützmembran in der Zellwand von Escherichia coli B. Z. Naturf. $17 b, 190$.

Pelzer, H. (1962). The chemical structure of two mucopeptides released from $E$. coli $B$ cell walls by lysozyme. Biochim. Biophys. Acta, 63, 229.

Primosigh, J., Pelzer, H., MaAss, D. \& Weidel, W. (1961). Chemical characterization of mucopeptides released from the $E$. coli $\mathbf{B}$ cell wall by enzymatic action. Biochim. Biophys. Acta, 46, 68.

Schocher, A. J., BaYley, S. T. \& Watson, R. W. (1962). Composition of purified mucopeptide from the cell wall of Aerabacter cloacae. Canad. J. Microbiol. 8, 89.

Shafa, F. \& Salton, M. R. J. (1960). Disaggregation of bacterial cell walls by anionic detergents. J. gen. Microbiol. 23, 137.

WeIDEL, W. (1951). Über die Zellmembran von Escherichia coli B. I. Mitteilung. Z. Naturf. $6 b, 251$.

Weidel, W. \& Primosigh, J. (1957). Die gemeinsame Wurzel der Lyse von Escherichia coli durch Penicillin oder durch Phagen. Z. Naturf. 12b, 421.

Weidel, W., Frank, H. \& Martin, H. H. (1960). The rigid layer of the cell wall of Escherichia coli strain B. J. gen. Microbiol. $22,158$.

Work, E. (1961). The mucopeptides of bacterial cell walls. J. gen. Microbiol. 25, 167.

\section{EXPLANATION OF PLATES}

\section{Plate 1}

Fig. 1. Cell walls of Salmonella gallinarum after treatment in a Mickle disintegrator with sodium dodecylsulphate. $\times 32,000$.

Fig. 2. Same as fig. 1, after treatment with trypsin. $\times \mathbf{3 2 , 0 0 0}$.

Fig. 3. Pure preparation of Salmonella gallinarum mucopolymer bags $(R$-layer). $\times \mathbf{8 2 , 0 0 0}$.

Plate 2

Fig. 4. Parallel chromatogram of lysozyme digests of Escherichia coli mucopolymer (C) and Salmonella gallinarum mucopolymer (S). Material in main spots of Escherichia coli chromatogram: $N$-acetyl-glucosaminyl- $N$-acetyl-muraminyl-L-alanyl-D-glutaminyl- $m$-diaminopimelic acid (upper spot $\left.=C_{5}\right)$; the lower spot $\left(=C_{6}\right)$ contains the same mucopeptide with an additional D-alanine attached to DAP as C-terminal (cf. Primosigh et al. 1961; Pelzer, 1962).

Fig. 5. Salmonella gallinarum cell walls after Mickle disintegrator treatment and trypsin digestion.

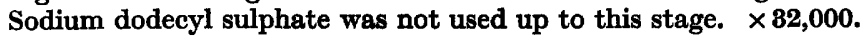

Fig. 6. Same as fig. 5 , after addition of sodium dodecyl sulphate. $\times \mathbf{3 2 , 0 0 0}$. 

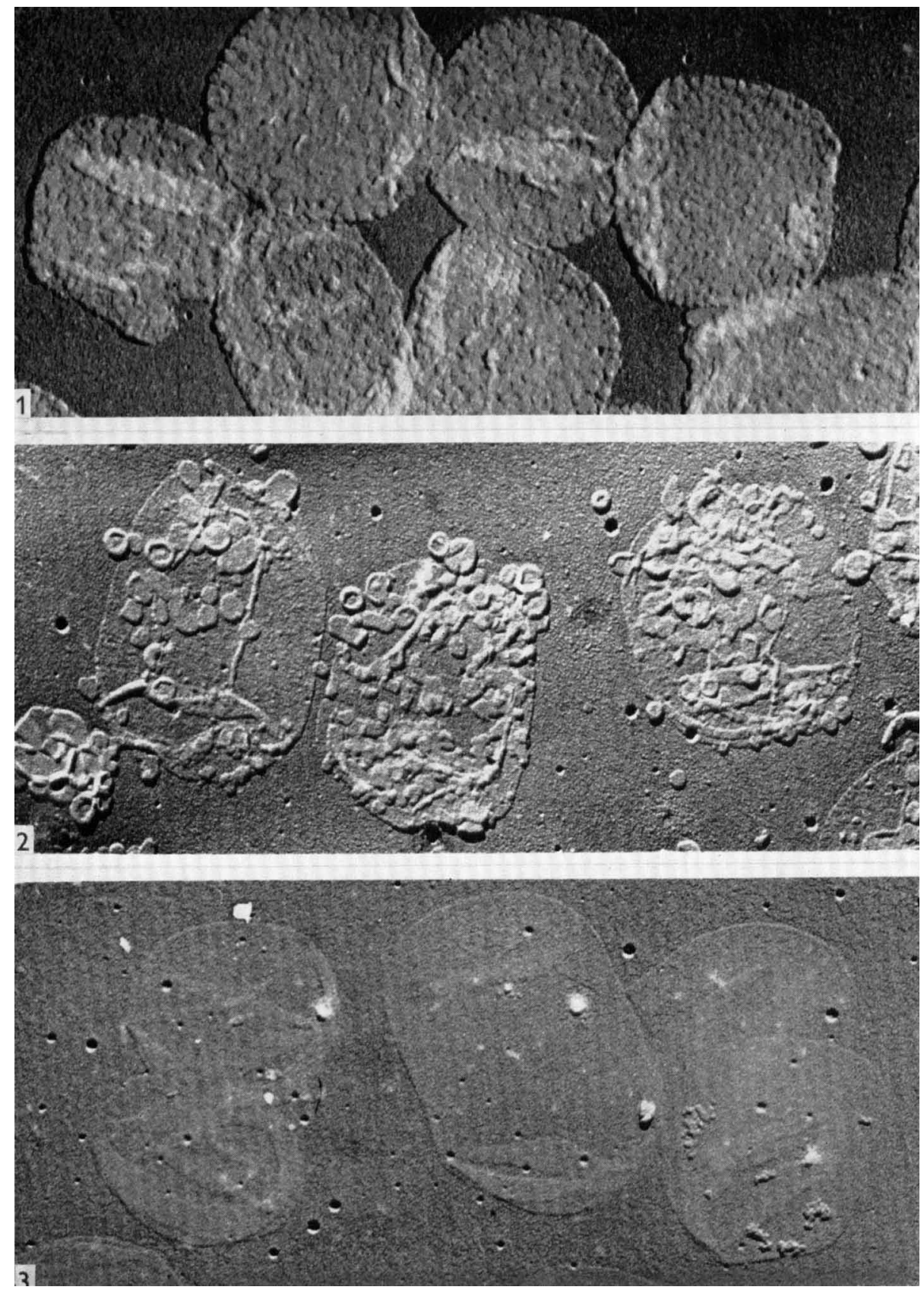

W. WEIDEL, H. FRANK AND W. LEUTGEB

(Facing $p .130)$ 


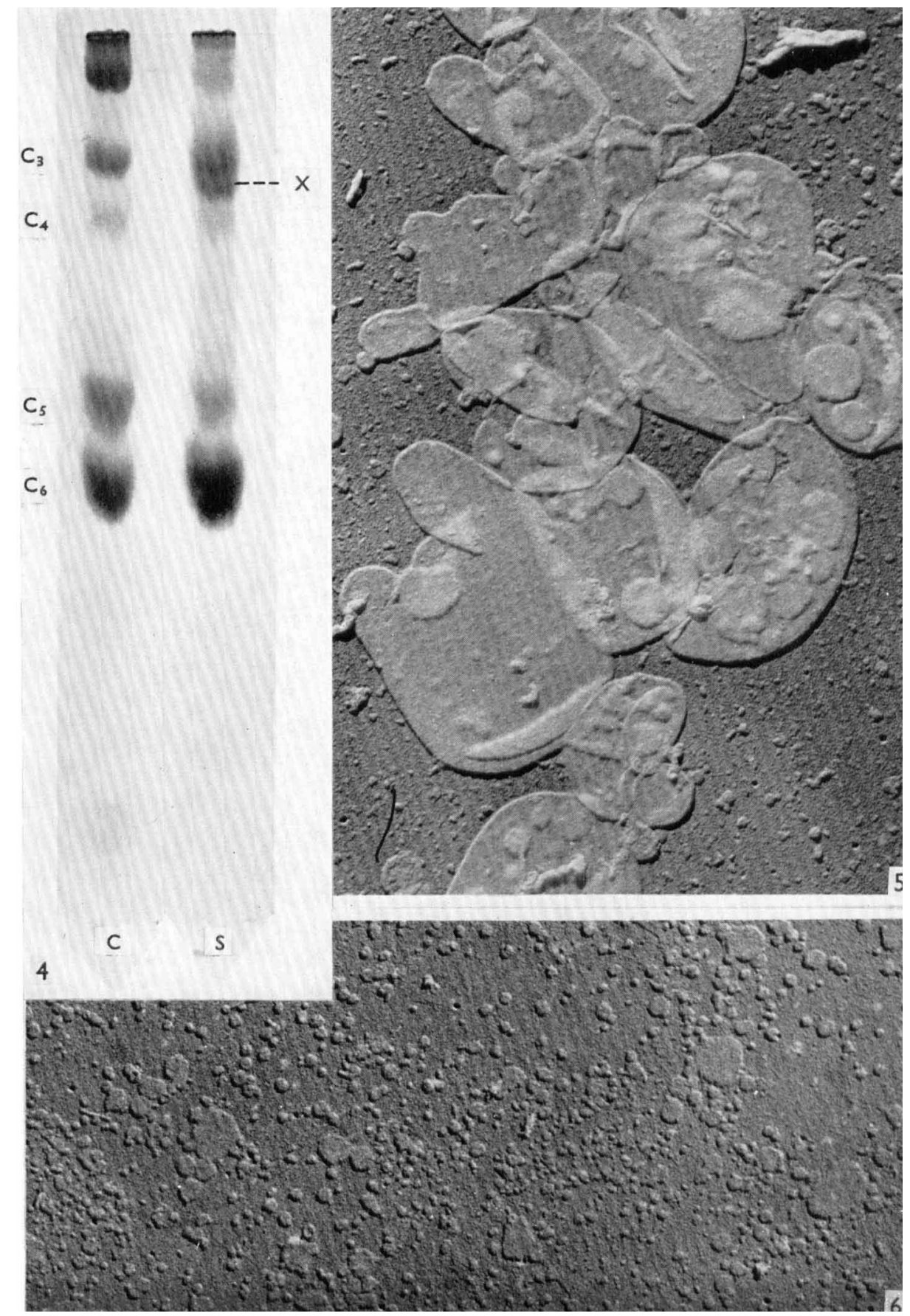

W. WEIDEI, H. FRANK AND W. LEUTGEB 